\title{
Papers
}

\section{Recent striking changes in histological differentiation and rate of human papillomavirus infection in squamous cell carcinoma of the lung in Okinawa, a subtropical island in southern Japan}

\author{
Jun Miyagi, Kyoko Tsuhako, Takao Kinjo, Teruo Iwamasa, Tsuneo Hirayasu
}

particular, at least in Okinawa, a subtropical island in southern Japan. (f Clin Pathol 2000;53:676-684)

Keywords: squamous cell carcinoma of the lung; histological differentiation; human papillomavirus

Lung cancer increased 40-fold and 36-fold in Japanese men and women, respectively, between 1950 and $1997 .^{1-3}$ Furthermore, the age adjusted mortality rate for lung cancer surpassed that of all other carcinomas in 1993 in Japan. ${ }^{1}$ Examination of the available epidemiological data for Okinawa, a subtropical island located between the East China Sea and Pacific Ocean, $2000 \mathrm{~km}$ south of mainland Japan, shows that lung cancer was the leading cause of death from malignant tumours in $1975,{ }^{4}$ and that the incidence of lung cancer has been the highest in Japan since that year. ${ }^{14}$ Furthermore, squamous cell carcinoma (SCC), especially the well differentiated form, is the most prevalent type in Okinawa, although it is relatively rare in mainland $\operatorname{Japan}^{56}$ and other countries. ${ }^{7-11}$ However, the frequency of well differentiated SCC cases has been declining on the island, particularly during the past five years.

Vincent et al reported in the 1960s that SCC was the most common tumour, representing about $50 \%$ of lung cancer cases. ${ }^{12}$ However, subsequent studies in the $1970 \mathrm{~s}$ on the incidence of major subtypes of lung cancer indicated that adenocarcinoma had moved ahead of SCC. ${ }^{12}{ }^{13}$ Unfortunately, the relative decrease in the incidence of SCC has been accompanied by an increase in adenocarcinoma. $^{231213}$

There is ample evidence indicating that cigarette smoking is the major cause of lung cancer. ${ }^{78101415}$ It is possible that the recent decrease in the frequency of SCC results, at least in part, from changes in smoking habits. However, the incidence of SCC remains high in Okinawa. ${ }^{45}$ This is interesting because the prevalence of smoking in general is not particularly high in Okinawa, being in fact lower than that in mainland Japan. ${ }^{16}$ We report data on lung cancer in Okinawa, and SCC in particular. In 1993, we examined SCC lesions
Accepted for publication 7 February 2000 development of SCC of the lung, affecting the histological differentiation of SCC in 
Table 1 Primers and probes used for detection of human papillomavirus (HPV) DNAs by the polymerase chain reaction (PCR) and Southern blot analysis

\begin{tabular}{|c|c|c|}
\hline & Primer/Probe & Product (bp) \\
\hline \multicolumn{3}{|l|}{ HPV-16 E7 } \\
\hline Sense & 5'-CCAGAGACAACTGATCTCTAC-3' & 171 \\
\hline Antisense & 5'-GTGTGTGCTTTGTACGCACAAC-3' & \\
\hline Probe & 5'-TAACCTTTTGTTGCAAGTGTGACTCTACGCTTCG-3' & \\
\hline \multicolumn{3}{|c|}{ 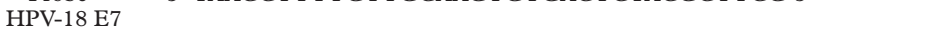 } \\
\hline Sense & 5'-GAGCCGAACCACAACGTCAC-3' & 152 \\
\hline Antisense & 5'-GGATGCACACCACGGACACA-3' & \\
\hline Probe & 5'-TCCAGCAGCTGTTTCTGAACACCCTG-3' & \\
\hline \multicolumn{3}{|c|}{ 年 } \\
\hline Sense & 5'-GCTGGATATGCAACAACAGTTG-3' & 189 \\
\hline Antisense & 5'-CATGCATGTTGTCCAGCAGTG-3' & \\
\hline Probe & 5'-GCTACCTGTGTCACAAACCG-3' & \\
\hline \multicolumn{3}{|l|}{ HPV-11 E6 } \\
\hline Sense & 5'-GCAGCGTGTGCCTGTTGCTTA-3' & 230 \\
\hline Antisense & 5'-AAGCAACGACCCTTCCACTGG-3' & \\
\hline Probe & 5'-CCTGTGTCACAAGCCGTTGTG-3' & \\
\hline \multicolumn{3}{|l|}{ HPV-16 E6 } \\
\hline Sense & 5'-GATGGGAATCCATATGCTGTA-3' & 240 \\
\hline Antisense & 5'-TCGACCGGTCCACCGACCCCT-3' & \\
\hline Probe & 5'-GCCACTGTGTCCTGAAGAAAAGC-3' & \\
\hline \multicolumn{3}{|l|}{ HPV-18 E6 } \\
\hline Sense & 5'-CAGTATACCCCATGCTGCATGCC-3' & 160 \\
\hline Antisense & 5'-TCGACCGGTCCACCGACCCCT-3' & \\
\hline Probe & 5'-GCCACTGTGTCCTGAAGAAAAGC-3' & \\
\hline
\end{tabular}

Table 2 Number of surgically resected lung cancer cases in Okinawa between 1986 and 1998

\begin{tabular}{lllllllll}
\hline Tumour type & 1986 & 1990 & 1993 & 1994 & 1995 & 1996 & 1997 & 1998 \\
\hline Squamous cell carcinoma & 25 & 36 & 43 & 25 & 34 & 37 & 22 & 21 \\
Adenocarcinoma & 21 & 28 & 39 & 25 & 42 & 34 & 34 & 65 \\
Adenosquamous carcinoma & 8 & 8 & 5 & 9 & 13 & 8 & 9 & 5 \\
Large cell carcinoma & 4 & 3 & 3 & 0 & 0 & 1 & 0 & 0 \\
Small cell carcinoma & 4 & 3 & 3 & 0 & 2 & 2 & 2 & 2 \\
Others & 6 & 4 & 1 & 2 & 2 & 1 & 5 & 1 \\
Total & 68 & 82 & 94 & 61 & 93 & 83 & 72 & 95 \\
\hline
\end{tabular}

In 1986, 10 of 25 cases of squamous cell carcinoma were peripherally located. In 1990, 15 of 36; in 1993, 21 of 43; in 1994, 13 of 25 ; in 1995, 18 of 34; in 1996, 24 of 37; in 1997, 14 of 22; and in 1998,10 of 21 were peripherally located.

for the presence of human papilloma virus (HPV) DNA. Surprisingly, many cases (79\%) were positive for HPV DNA. ${ }^{5}$ At that time, $\mathrm{we}^{5}$ and others ${ }^{17} 18$ also reported that HPV DNA was found in only $10-30 \%$ of SCC cases in mainland Japan. In our present study, we report the proportion of SCC cases positive for HPV DNA, and changes in tumour differentiation during a 12 year period, extending from 1986 to 1998.

\section{Materials and methods}

TISSUE SAMPLES

Samples were obtained from the National Okinawa Hospital, Ryukyu University Hospital, and the Naha Centre of the Doctor's Union. Samples comprised all the surgically removed carcinomas at these hospitals between 1986 and 1998. There was no secondary selection. More than $70 \%$ of patients in Okinawa underwent surgery in the National Okinawa Hospital; the remaining few cases were from the Ryukyu University Hospital and affiliated hospitals. Our University Medical School was opened in 1980, and up to 1985 we examined only $30-50 \%$ of all the surgically removed samples each year in Okinawa. Although those data are not included in our present study, well differentiated squamous cell carcinoma was commonly observed during that period. Most patients in our study were farmers or fishermen, with no miners or heavy industry workers because the latter two industries do not exist in Okinawa.
Table 3 Histological differentiation of squamous cell carcinoma cases (1986-98)

\begin{tabular}{lllll}
\hline \multicolumn{3}{c}{ Differentiation } & & \\
\cline { 2 - 4 } & Well & Moderately & Poorly & Total \\
\hline 1986 & 17 & 8 & 0 & 25 \\
1990 & 26 & 9 & 1 & 36 \\
1993 & 28 & 13 & 2 & 43 \\
1994 & 15 & 10 & 0 & 25 \\
1995 & 8 & 19 & 7 & 34 \\
1996 & 8 & 20 & 9 & 37 \\
1997 & 4 & 13 & 5 & 22 \\
1998 & 5 & 12 & 4 & 21 \\
\hline
\end{tabular}

HISTOLOGICAL EXAMINATION AND NON-ISOTOPIC IN SITU HYBRIDISATION

Tumour tissue samples were fixed in $10 \%$ phosphate buffered formalin and processed using standard procedures. Dewaxed sections ( $4 \mu \mathrm{m}$ thick) were stained with haematoxylin and eosin, Gomori's silver impregnation, periodic acid Schiff, and alcian blue. Tumours were classified into the following categories according to the criteria of the Japan Lung Society ${ }^{19}$ : SCC, small cell carcinoma, adenocarcinoma, large cell carcinoma, adenosquamous carcinoma, carcinoid tumour, bronchial gland carcinoma, and miscellaneous tumours. Included within the adenocarcinomas were acinar adenocarcinomas, papillary adenocarcinomas, bronchioloalveolar carcinomas, and solid carcinomas with mucin formation. Small cell carcinoma included oat cell carcinoma, intermediate cell type, and combined oat cell carcinoma. Large cell carcinomas included large cell carcinoma and variants, and giant cell carcinoma. Adenosquamous carcinomas were composed of at least $20 \%$ each of SCC and adenocarcinoma. ${ }^{19}$ Both components were at least moderately well differentiated. ${ }^{20}$ Carcinoid tumours, bronchial gland carcinomas, adenoid cystic carcinomas, mucoepidermoid carcinomas, and unclassified carcinomas were categorised as "others".

Immunohistochemical demonstration of p53 protein was performed using $4 \mu \mathrm{m}$ dewaxed sections. The tissue was treated with anti-p53 protein monoclonal antibody $\mathrm{Ab}-2$ (Oncogene Research Products, Calbiochem, Cambridge, Massachusetts, USA) after microwave oven heating in $10 \mathrm{mM}$ sodium citrate buffer ( $\mathrm{pH}$ 6.0). Immunohistochemical studies were carried out by the avidin-biotin-peroxidase method.

Non-isotopic in situ hybridisation (NISH) was performed on all specimens using HPV types $6,11,16$, and 18 biotin labelled probes and a proprietary NISH detection system (Dako, Carpinteria, California, USA). NISH was carried out according to the method of Cooper and colleagues ${ }^{21}$ and the manufacturer's instructions. Sections were digested with proteinase K (Merck, Tokyo, Japan) at a concentration of $2 \mu \mathrm{g} / \mathrm{ml}$ in $5 \mathrm{mM}$ Tris $/ \mathrm{HCl}$ buffer, $\mathrm{pH} 7.4$, for 15 minutes at $37^{\circ} \mathrm{C}$, then incubated with prehybridisation solution containing $2 \times$ SSC (sodium saline citrate), $\mathrm{pH} 7.2$, $10 \%$ dextran sulphate (wt $/ \mathrm{vol}$ ), $400 \mu \mathrm{g} / \mathrm{ml}$ of sonicated herring sperm DNA, and 50\% formamide (vol/vol). Denaturation of probe and target DNA in the sections was performed 

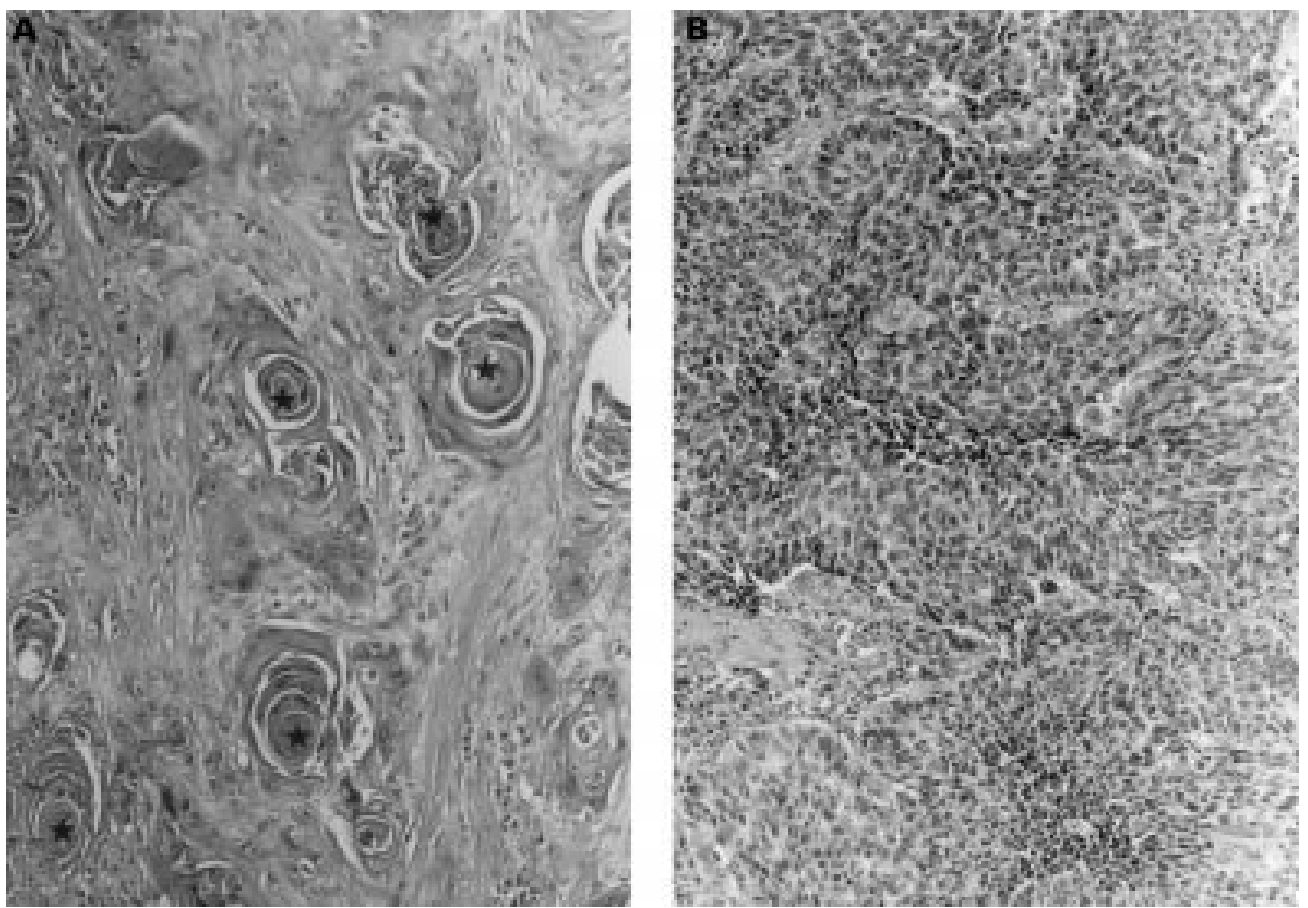

Figure 1 (A) A representative example of well differentiated squamous cell carcinoma of the lung showing common histological features in such tumours in Okinawa (case detected in 1993). Note the presence of keratin pearls (indicated by a star). Haematoxylin and eosin staining; magnification, $\times 150$. (B) A representative example of poorly differentiated squamous cell carcinoma of the lung (case detected in 1998). Haematoxylin and eosin staining; magnification, $\times 180$.

simultaneously on a hot plate $\left(90^{\circ} \mathrm{C}\right)$ for two minutes. Hybridisation was subsequently carried out using $1 \mu \mathrm{g} / \mathrm{ml}$ of biotinylated HPV DNA by incubating the sections overnight in a humidified chamber at $37^{\circ} \mathrm{C}$. Biotin was detected using alkaline phosphatase labelled streptavidin. 5-Bromo-4-chloro-3-indolyl phosphate and nitroblue tetrazolium were used as substrate and chromogen, respectively.

DETECTION OF HPV TYPES $6,11,16$, AND 18 DNA BY PCR

DNA samples from SCC lesions were prepared according to the methods described by Impraim et al. ${ }^{22}$ The $110 \mathrm{bp} \beta$-globin gene was detected in all DNA samples according to the method of Saiki et $a l^{23}$ using their primers

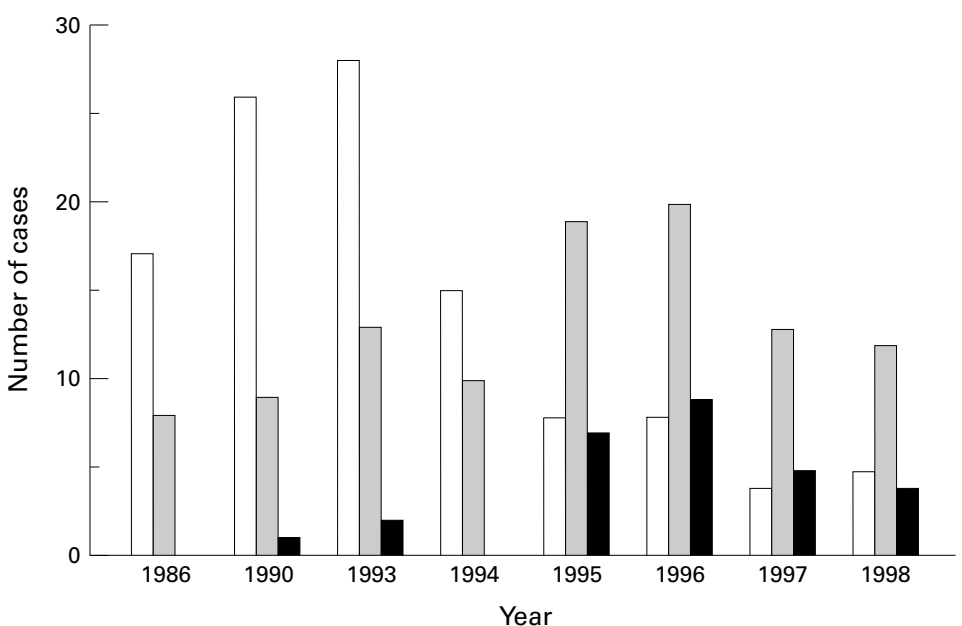

Figure 2 Squamous cell carcinoma (SCC) of the lung: changes in the histological features. Open bars, well differentiated SCC; shaded bars, moderately differentiated SCC; black bars, poorly differentiated SCC.
$\left(\mathrm{PCO}_{3}\right.$ and $\left.\mathrm{PCO}_{4}\right)$. Table 1 lists the primers and probes for HPV-16 and HP-18 E7 used in these experiments. The primers for the E6 regions of HPV types 6, 11, 16, and 18, and probes for Southern blot analysis were similar to those reported by McNicol et al (table 1). ${ }^{24}$ The PCR reaction mixture contained $10 \mathrm{mM}$ Tris/ $\mathrm{HCl}$, $\mathrm{pH} 8.3,50 \mathrm{mM} \mathrm{KCl}, 1.5 \mathrm{mM} \mathrm{MgCl}_{2}, 0.01 \%$ gelatin, $0.4 \mathrm{mM}$ each of four dNTPs, $0.32 \mu \mathrm{g}$ of each primer, and $2.4 \mathrm{U}$ Taq DNA polymerase (Cetus-Takara, Otsu, Japan). The reaction conditions were similar to those reported previously ${ }^{52}$ : annealing at $62^{\circ} \mathrm{C}$ for three minutes, denaturation at $94^{\circ} \mathrm{C}$ for two minutes, and extension at $74^{\circ} \mathrm{C}$ for four minutes for 40 cycles. The amplified DNA was transferred on to nylon membranes (Hybond-N ${ }^{+}$; Amersham Life Science, Buckinghamshire, UK) after routine polyacrylamide gel $(10 \%)$ electrophoresis. Using a probe and the Amersham system (ECL 3'-oligolabelling and detection

Table 4 Number of human papilloma virus (HPV) DNA positive cases

\begin{tabular}{llllllll}
\hline \multicolumn{4}{c}{ Type of HPV } & & \multicolumn{3}{l}{ Two } \\
\cline { 2 - 6 } & 6 & 11 & 16 & 18 & $\begin{array}{l}\text { Three } \\
\text { types }\end{array}$ & Total \\
\hline 1993 & 2 & 0 & 5 & 5 & 17 & 5 & 34 \\
1995 & 5 & 6 & 5 & 3 & 4 & 0 & 23 \\
1996 & 3 & 3 & 1 & 4 & 2 & 0 & 13 \\
1997 & 0 & 2 & 1 & 1 & 1 & 0 & 5 \\
1998 & 1 & 3 & 0 & 1 & 0 & 0 & 5 \\
\hline
\end{tabular}

The data for 1993 have been reported previously. ${ }^{5}$

HPV double positive cases were as follows: in 1993, 13 cases were positive for HPV-16 and HPV-18, two were positive for HPV-6 and HPV-16, and another two for HPV-6 and HPV-18. In 1995, one was positive for HPV-6 and HPV-16, and three were positive for HPV-16 and HPV-18. In 1996, one each was positive for HPV-6 and HPV-18, and HPV-16 and HPV-18. In 1997, one was positive for HPV-16 and HPV-18. In 1998, no HPV double positive cases were found. 
Table 5 Histological differentiation of squamous cell carcinoma (SCC) and detection of human papillomavirus $(H P V)$ by the polymerase chain reaction (PCR) and non-isotopic in situ hybridisation (NISH) in 1995-8

\begin{tabular}{llllll}
\hline Case & Sex & Age & $\begin{array}{l}\text { Histological } \\
\text { differentiation }\end{array}$ & $\begin{array}{l}\text { Detected type of } \\
\text { HPV by PCR }\end{array}$ & NISH \\
no. & NSH &
\end{tabular}

Histological differentiation of SCC and detection of HPV by PCR and NISH in 1995

\begin{tabular}{|c|c|c|c|c|c|}
\hline 1 & $\mathrm{~m}$ & 67 & W & $6^{\star}, 18$ & 18 \\
\hline 2 & $\mathrm{~m}$ & 62 & W & 16 & 16 \\
\hline 3 & $\mathrm{~m}$ & 70 & W & $6^{\star}, 18$ & 18 \\
\hline 4 & $\mathrm{~m}$ & 74 & W & $6^{\star}, 11$ & 11 \\
\hline 5 & $\mathrm{~m}$ & 68 & W & 16 & 16 \\
\hline 6 & $\mathrm{~m}$ & 72 & W & 11 & 11 \\
\hline 7 & $\mathrm{~m}$ & 66 & W & $11^{\star}, 16$ & 16 \\
\hline 8 & $\mathrm{f}$ & 73 & W & 16 & 16 \\
\hline 9 & $\mathrm{~m}$ & & M & $6^{\star}$ & \\
\hline 10 & $\mathrm{~m}$ & 73 & M & 11 & 11 \\
\hline 11 & $\mathrm{~m}$ & 87 & M & & \\
\hline 12 & $\mathrm{~m}$ & 64 & M & 18 & 18 \\
\hline 13 & $\mathrm{~m}$ & 73 & M & 11 & 11 \\
\hline 14 & f & & M & 18 & 18 \\
\hline 15 & $\mathrm{~m}$ & 68 & M & & \\
\hline 16 & f & 75 & M & & \\
\hline 17 & $\mathrm{~m}$ & 44 & M & 16 & 16 \\
\hline 18 & $\mathrm{f}$ & 73 & M & & \\
\hline 19 & $\mathrm{~m}$ & 67 & M & 11 & 11 \\
\hline 20 & $\mathrm{~m}$ & 73 & M & 6 & 6 \\
\hline 21 & $\mathrm{~m}$ & & M & & \\
\hline 22 & $\mathrm{~m}$ & 66 & M & 18 & 18 \\
\hline 23 & $\mathrm{~m}$ & & M & 6 & 6 \\
\hline 24 & $\mathrm{~m}$ & 75 & M & $16^{\star}$ & \\
\hline 25 & $\mathrm{~m}$ & 63 & M & 11 & 11 \\
\hline 26 & $\mathrm{~m}$ & 64 & M & & \\
\hline 27 & $\mathrm{~m}$ & 69 & M & & \\
\hline 28 & $\mathrm{~m}$ & 66 & $\mathrm{P}$ & $6^{\star}$ & \\
\hline 29 & $\mathrm{~m}$ & & P & $6^{\star}$ & 6 \\
\hline 30 & $\mathrm{~m}$ & 68 & P & & \\
\hline 31 & $\mathrm{~m}$ & 70 & P & & \\
\hline 32 & $\mathrm{~m}$ & 70 & $\mathrm{P}$ & 11 & 11 \\
\hline 33 & $\mathrm{~m}$ & 73 & $\mathrm{P}$ & & \\
\hline 34 & $\mathrm{~m}$ & 78 & $\mathrm{P}$ & & \\
\hline & $\begin{array}{l}\text { sical } \\
\text { NIS }\end{array}$ & $\begin{array}{l}\text { feren } \\
n 19\end{array}$ & ion 0 & letection of & $P C R$ \\
\hline 1 & $\mathrm{~m}$ & 66 & W & & \\
\hline 2 & f & & W & 11 & 11 \\
\hline 3 & $\mathrm{f}$ & 73 & W & 18 & 18 \\
\hline 4 & $\mathrm{~m}$ & 69 & W & 6 & 6 \\
\hline 5 & f & 64 & W & 18 & 18 \\
\hline 6 & $\mathrm{~m}$ & 54 & W & 18 & 18 \\
\hline 7 & $\mathrm{~m}$ & 83 & $\mathrm{~W}$ & & \\
\hline 8 & $\mathrm{~m}$ & 53 & W & 6 & 6 \\
\hline 9 & $\mathrm{~m}$ & 67 & M & & \\
\hline 10 & $\mathrm{~m}$ & 62 & M & & \\
\hline 11 & $\mathrm{~m}$ & & M & & \\
\hline 12 & $\mathrm{~m}$ & 66 & M & 16 & 16 \\
\hline 13 & $\mathrm{~m}$ & 87 & M & $16^{\star}, 18$ & 16 \\
\hline 14 & $\mathrm{~m}$ & 64 & M & $11^{\star}$ & \\
\hline 15 & $\mathrm{~m}$ & 73 & M & 11 & 11 \\
\hline 16 & $\mathrm{~m}$ & 68 & M & & \\
\hline 17 & $\mathrm{~m}$ & 70 & M & & \\
\hline 18 & $\mathrm{f}$ & 75 & M & 6 & 6 \\
\hline 19 & $\mathrm{~m}$ & 44 & M & & \\
\hline 20 & f & 74 & M & & \\
\hline 21 & f & 73 & M & & \\
\hline 22 & $\mathrm{~m}$ & 67 & M & & \\
\hline 23 & $\mathrm{~m}$ & 68 & M & & \\
\hline 24 & $\mathrm{~m}$ & 73 & M & & \\
\hline 25 & $\mathrm{~m}$ & & M & & \\
\hline 26 & $\mathrm{~m}$ & 65 & M & & \\
\hline 27 & $\mathrm{~m}$ & & M & & \\
\hline 28 & $\mathrm{~m}$ & 75 & M & & \\
\hline 29 & $\mathrm{~m}$ & 73 & $\mathrm{P}$ & & \\
\hline 30 & $\mathrm{~m}$ & 72 & $\mathrm{P}$ & & \\
\hline 31 & $\mathrm{~m}$ & & $\mathrm{P}$ & $16^{\star}, 18$ & 18 \\
\hline 32 & $\mathrm{~m}$ & 68 & $\mathrm{P}$ & & \\
\hline 33 & $\mathrm{~m}$ & 70 & $\mathrm{P}$ & & \\
\hline 34 & $\mathrm{~m}$ & 70 & $\mathrm{P}$ & & \\
\hline 35 & $\mathrm{~m}$ & 73 & $\mathrm{P}$ & 18 & 18 \\
\hline 36 & $\mathrm{~m}$ & 63 & $\mathrm{P}$ & & \\
\hline 37 & $\mathrm{~m}$ & 78 & P & & \\
\hline
\end{tabular}

system), Southern blot analysis was carried out according to the manufacturer's instructions.

The sensitivity of the PCR method ${ }^{26}$ was tested with various concentrations of $\mathrm{HPV}$ types 11,16 , and 18 in plasmid pBR 322 and HPV-6 in plasmid pML, which were obtained from the Japanese Cancer Research Resource
Table 5 continued

\begin{tabular}{|c|c|c|c|c|c|}
\hline $\begin{array}{l}\text { Case } \\
\text { no. }\end{array}$ & Sex & Age & $\begin{array}{l}\text { Histological } \\
\text { differentiation }\end{array}$ & $\begin{array}{l}\text { Detected type of } \\
\text { HPV by PCR }\end{array}$ & NISH \\
\hline \multicolumn{6}{|c|}{$\begin{array}{l}\text { Histological differentiation of SCC and detection of HPV by PCR } \\
\text { and NISH in } 1997\end{array}$} \\
\hline 1 & $\mathrm{~m}$ & 76 & $\mathrm{~W}$ & $16,18^{\star}$ & 16 \\
\hline 2 & $\mathrm{~m}$ & 63 & W & 11 & 11 \\
\hline 3 & $\mathrm{~m}$ & 80 & W & 16 & 16 \\
\hline 4 & $\mathrm{~m}$ & 69 & W & & \\
\hline 5 & $\mathrm{~m}$ & 71 & $M$ & & \\
\hline 6 & $\mathrm{~m}$ & & M & 18 & 18 \\
\hline 7 & $\mathrm{~m}$ & 67 & $M$ & & \\
\hline 8 & $\mathrm{~m}$ & 68 & $M$ & & \\
\hline 9 & f & 67 & $M$ & 11 & 11 \\
\hline 10 & $\mathrm{~m}$ & 82 & M & & \\
\hline 11 & $\mathrm{~m}$ & 68 & $M$ & & \\
\hline 12 & $\mathrm{~m}$ & 68 & $M$ & & \\
\hline 13 & $\mathrm{~m}$ & 73 & $M$ & & \\
\hline 14 & $\mathrm{~m}$ & 72 & $M$ & & \\
\hline 15 & $\mathrm{f}$ & 77 & M & & \\
\hline 16 & $\mathrm{~m}$ & 68 & M & & \\
\hline 17 & $\mathrm{~m}$ & 70 & M & & \\
\hline 18 & $\mathrm{~m}$ & 82 & $\mathrm{P}$ & & \\
\hline 19 & $\mathrm{f}$ & 65 & $\mathrm{P}$ & & \\
\hline 20 & $\mathrm{~m}$ & 83 & $\mathrm{P}$ & & \\
\hline 21 & $\mathrm{~m}$ & 67 & $\mathrm{P}$ & & \\
\hline 22 & $\mathrm{~m}$ & & $\mathrm{P}$ & & \\
\hline \multicolumn{6}{|c|}{$\begin{array}{l}\text { Histological differentiation of SCC and detection of HPV by PCR } \\
\text { and NISH in } 1998\end{array}$} \\
\hline 1 & $\mathrm{~m}$ & & W & 11 & 11 \\
\hline 2 & $\mathrm{f}$ & & W & $11^{\star}$ & \\
\hline 3 & $\mathrm{~m}$ & & W & & \\
\hline 4 & $\mathrm{~m}$ & & W & & \\
\hline 5 & $\mathrm{~m}$ & & W & 18 & 18 \\
\hline 6 & $\mathrm{f}$ & & M & & \\
\hline 7 & $\mathrm{~m}$ & & $M$ & 11 & 11 \\
\hline 8 & $\mathrm{~m}$ & & $M$ & & \\
\hline 9 & $\mathrm{~m}$ & & $M$ & & \\
\hline 10 & $\mathrm{~m}$ & & M & & \\
\hline 11 & $\mathrm{~m}$ & & M & & \\
\hline 12 & $\mathrm{~m}$ & & M & & \\
\hline 13 & $\mathrm{f}$ & & $M$ & 6 & 6 \\
\hline 14 & $\mathrm{~m}$ & & $M$ & & \\
\hline 15 & $\mathrm{~m}$ & & M & & \\
\hline 16 & $\mathrm{f}$ & & M & & \\
\hline 17 & $\mathrm{~m}$ & & $M$ & & \\
\hline 18 & $\mathrm{~m}$ & & $\mathrm{P}$ & & \\
\hline 19 & f & & $\mathrm{P}$ & & \\
\hline 20 & $\mathrm{~m}$ & & $\mathrm{P}$ & & \\
\hline 21 & $\mathrm{~m}$ & & $\mathrm{P}$ & & \\
\hline
\end{tabular}

PCR was carried out using the primers in table 1

${ }^{\star}$ Was not detected by the use of the type specific primers.$^{27}$ $\mathrm{f}$, female; $\mathrm{m}$, male; $\mathrm{M}$, moderately differentiated; $\mathrm{P}$, poorly differentiated; W, well differentiated.

Bank, with permission from Dr Zur Hausen. Caski cells and HeLa cells were used as positive controls.

The detection of HPV DNA by PCR was carried out by two authors (JM and TH) separately in separate rooms to confirm the data blindly, using two different PCR cyclers (ASTEL and PL800; Astec, Fukuoka, Japan). Furthermore, using the general primers (GP5/6) and type specific primers, according to the method of Walboomers et al, ${ }^{27}$ the detection of HPV by PCR was also carried out separately by two authors (TK and KT).

SEQUENCE ANALYSIS OF PCR PRODUCTS

PCR products were extracted from the agarose gel. The extracted DNA was cloned into T-vector prepared from Bluescript (Stratagene, La Jolla, California, USA), according to the method of Marchuk et al. ${ }^{28}$ Bluescript plasmid was digested with EcoRV, and incubated with

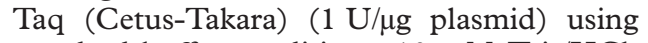
standard buffer conditions, $10 \mathrm{mM}$ Tris/ $\mathrm{HCl}$, $\mathrm{pH} 8.3,50 \mathrm{mM} \mathrm{KCl}, 1.5 \mathrm{mM} \mathrm{MgCl}_{2}$, and $200 \mu \mathrm{g} / \mathrm{ml}$ bovine serum albumin in the presence of $2 \mathrm{mM}$ dTTP for two hours at $70^{\circ} \mathrm{C}$. Sequence analysis was carried out using 


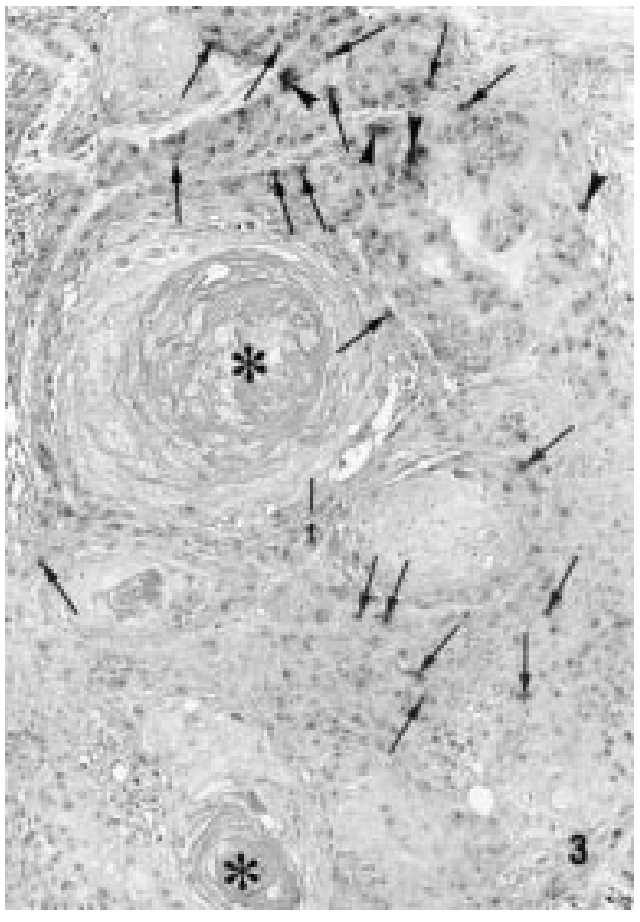

Figure 3 Detection of HPV DNA in squamous cell carcinoma by non-isotopic in situ hybridisation. Note the presence of integrated (arrows) and episomal (arrowheads) forms of HPV in tumour cells (the same well differentiated squamous cell carcinoma case shown in fig 1). Keratin pearls indicated by an asterisk. Magnification, $\times 250$

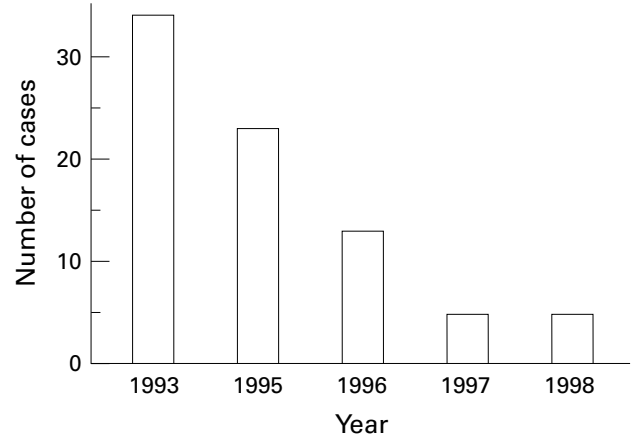

Figure 4 Squamous cell carcinoma of the lung. Changes in the incidence of human papillomavirus positive cases.

the Hitachi SQ 5500 DNA sequencer (Hitachi, Tokyo, Japan).

STATISTICAL ANALYSIS

Statistical analysis was performed using the Mantel-Haentzel $\chi^{2}$ method, and multiple regression analysis (Statistical Analysis System, SAS Institute Inc, Cary, North Carolina, USA). The level of significance was set at $\mathrm{p}<0.05$.

\section{Results}

HISTOLOGICAL EXAMINATION

During the study period (1986-98), 1109 surgically excised lung tumours were diagnosed microscopically by two pathologists (TI and $\mathrm{JM}$ ), and re-examined by one pathologist (TI) for our report. Among them, 648 cases $(\mathrm{SCC}=243)$ in 1986,1990 , and $1993-8$ are listed in table 2 . The total number of SCC cases (1986-98) was 421. Up until 1993, the number of SCC cases was higher than that of adenocarcinoma cases, but in 1995, for the first time, the number of adenocarcinoma cases surpassed that of SCC cases (table 2). Although we have seen a disproportionally high number of well differentiated SCC cases in Okinawa compared with mainland Japan up to the present time (table 3; figs 1 and 2), the proportion has been decreasing since 1995. Peripherally located SCC cases have also been increasing, whereas in 1986 centrally located tumours were found more frequently. Figure 1A shows the histological features of a representative well differentiated SCC in an Okinawan patient. Pearl formations are conspicuous. Most patients with SCC were men (379 of 421 SCC cases between 1986 and $1998 ; 90 \%$ ), and the well differentiated form was frequently seen (table 3). The well differentiated type was rare in women (eight in the 42 cases between 1986 and 1998). The ratio of male to female patients in each year did not change significantly during the study period. Most patients with SCC (389 of 421; $92 \%$ ) were heavy smokers (>10 cigarettes/ day), whereas the others were non-smokers or light smokers. The mean (SD) age of patients with SCC was 68.1 years (8.6), and it did not change significantly over the study period (6669). The number of SCC cases was lower than that of adenocarcinoma cases in 1995, 1997, and 1998, but most patients were heavy smokers; only one in 1995 and 1996, three in 1997, and five in 1998 were not heavy smokers. Immunohistochemically, overexpression of the p53 protein was detected in 10 cases in 1986, 18 in 1993, eight in 1994, 13 in 1995, 16 in 1996, eight in 1997, and seven in 1998. The ratio of immunohistochemically p53 protein positive cases was in the range $33-44 \%$ throughout the study period.

DETECTION OF HPV DNA BY NISH AND PCR

One hundred and fifty seven SCC cases in $1993(n=43)$ and 1995-8 $(n=114)($ table 2$)$ were analysed by NISH and PCR.

As reported previously, ${ }^{5}$ lower limits of 55 and 77 viral copies of HPV-16 and HPV-18 E7 regions, respectively, were detected using Southern blot analysis with chemiluminescent oligonucleotide probes. For HPV types 6, 11, 16 , and $18 \mathrm{E} 6$, lower limits of 85, 740, 55, and 7700 viral copies were detected using $\mathrm{McNi}$ col's primers and probes. ${ }^{24}$ The copy numbers were estimated using serial dilution of each type of HPV in plasmid. The sensitivity of PCR varied with the primers and probes used. Cases where either one or both of the E6 and E7 regions were detected were counted as positive for HPV DNA. The sensitivity of the PCR using the type specific primers of Walboomers and colleagues ${ }^{27}$ was also tested, and lower limits of about $740,800,100$, and 80 copies of the L2 region of HPV-6 and the L1 regions of HPV types 11,16 , and 18, respectively, were detected. In dual or triple positive cases, one type of HPV DNA was detected at greater than 1000 copies/10 paraffin wax sections ( $\sim 10 \mathrm{~mm}^{2} \times 4 \mu \mathrm{m}$ in thickness), whereas the second or second and third type was detected at a much lower concentration $(<200-300$ 


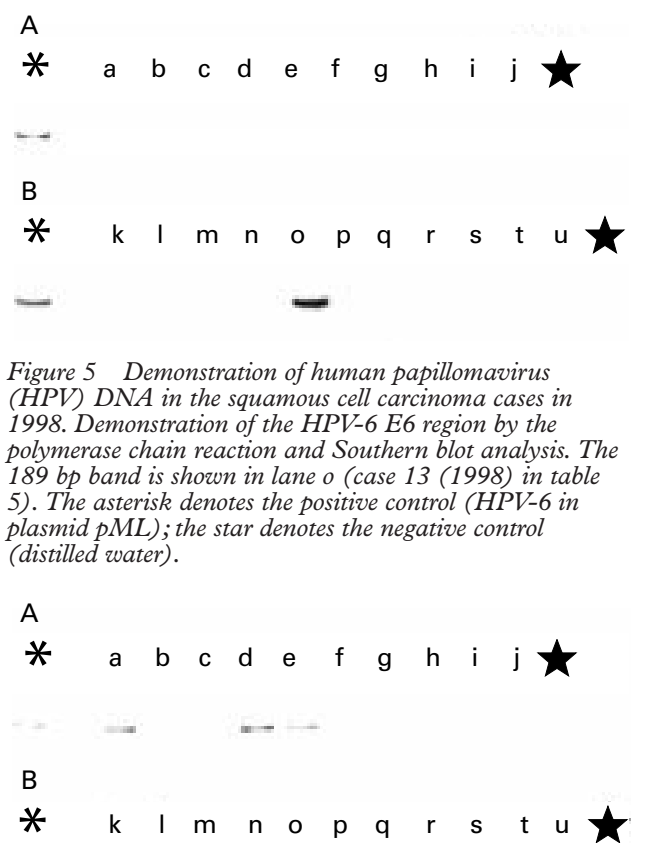
(HPV-11) E6 region in the squamous cell carcinoma cases in 1998 by the polymerase chain reaction (PCR) and Southern blot analysis. Positive bands (230 bp) are shown in lanes $a$, $d$, and $e$ (cases 1,2, and 7 (1998) in table 5). The asterisk denotes the positive control (HPV-11 in plasmid pBR 322); the star denotes the negative control (distilled water).

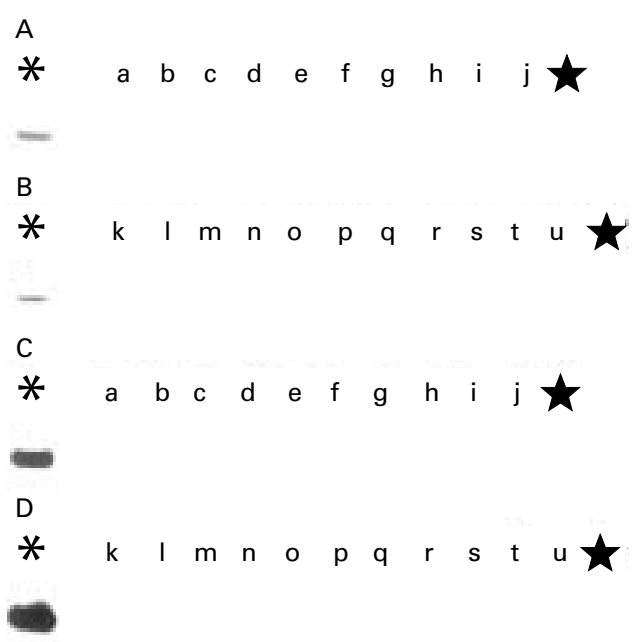

Figure 7 ( $A$ and $B)$ Demonstration of the human papillomavirus 16 (HPV-16) E6 region in the squamous cell carcinoma cases in 1998 by the polymerase chain reaction (PCR) and Southern blot analysis. No positive bands (240 bp) are shown. (C and D) Demonstration of the HPV-16 E7 region by PCR and Southern blot analysis. No positive bands (171 bp) are shown. The asterisk denotes the positive control (HPV-16 in plasmid pBR 322). The star denotes the negative control (distilled water).

copies/10 paraffin wax sections). In single type HPV infected cases, $>1000$ copies of HPV were detected. Copy numbers of HPV were measured using serially diluted DNA samples and comparison with known copy number HPVs in plasmids.

In 1993, we reported the incidence of HPV DNA in Okinawan SCC cases $(n=43) .{ }^{5}$ In

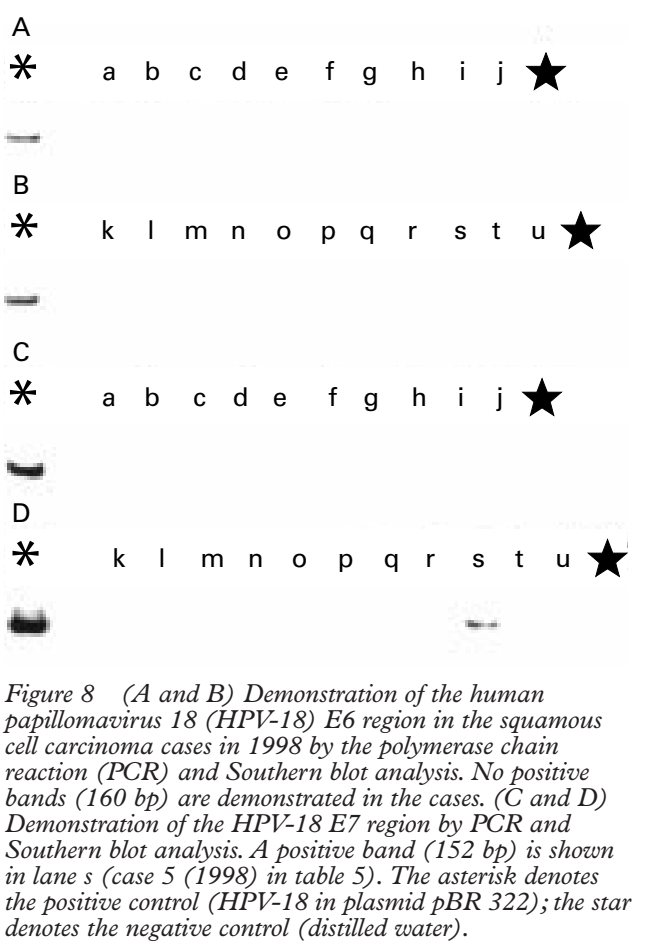

that study, $34(79 \%)$ cases were positive for HPV DNA. Of these, 13 cases were positive for HPV-16 and HPV-18, two cases were positive for HPV-6 and HPV-16, another two for HPV-6 and HPV-18, and five cases were triple positive for HPV types 6, 16, and 18. In these cases, the copy number of one of the two or one of the three types of HPV was predominant, implying that the second, or the second and third, type of HPV represented a superimposed infection. Using Southern hybridisation and $\mathrm{NISH}$, in our present study we detected both episomal and integrated forms of HPV (fig 3). However, we found that since 1995 the number of HPV positive cases has been steadily decreasing. In 1995, there were 23 (68\%) HPV positive cases; in 1996, 13 (35\%); in 1997, five (23\%); and in 1998, five (24\%) (tables 4 and 5; fig 4). In 1995, four cases were positive for two types of HPV, but only two cases were in 1996 and 1997. No cases with triple type HPV have occurred since 1995. The PCR products were confirmed as HPV DNA by Southern blot analysis (figs 5-8) and sequence analysis (data not shown). The results obtained by JM and $\mathrm{TH}$, and TK and KT agreed, but HPV types 31 and 33 were not detected using Walboomers's primers. ${ }^{27}$ Examination of our data showed diminishing numbers of both SCC cases, especially the well differentiated form, and HPV positive cases in recent years. There was a trend towards an increased number of poorly differentiated cancers (table 3; fig 2), most of which were negative for HPV. HPV was detected mainly in moderately or well differentiated cancers (table 5). Among HPV positive cases, 20 of 23 in 1995, 11 of 13 in 1996, five of five in 1997, and four of five in 1998 were moderately or well differentiated cases. HPV DNA was found frequently in well differentiated SCC ( $\mathrm{p}=0.05)$ using the $\chi^{2}$ and multiple regression analysis. However, no significant 
correlation was found between detection of HPV DNA and the degree of smoking by similar multiple regression analysis.

\section{Discussion}

Although we have seen a disproportionately large number of well differentiated SCC cases in Okinawa up to the present time, ${ }^{52}$ the frequency of these tumours has been steadily decreasing in recent years. Since 1995, the proportion of SCC, especially that of well differentiated tumours, has greatly decreased, and the number of adenocarcinoma cases surpassed that of SCC. This trend has also been observed in the past 20-30 years in mainland Japan as well as other countries. ${ }^{3891230}$ In the 1950s, well differentiated SCCs were found frequently in both mainland Japan and other countries. ${ }^{69}$ A large number of well differentiated SCCs of the lung were reported in the $1950 \mathrm{~s}$ in mainland Japan. ${ }^{6}$ However, most SCCs of the lung identified in recent years have been moderately or poorly differentiated forms. ${ }^{781014}$ Saldana et al reported recently that well differentiated SCC of the lung is relatively rare in the USA. ${ }^{15}$ The criteria for well, moderately, and poorly differentiated tumours might vary slightly between pathologists, but the basic histological findings of SCC have remained unchanged for many years, including the presence of keratinisation (for example, pearl formation), prominent desmosomes (intercellular bridges), and bundles of intermediate filaments (keratin) frequently terminating on desmosomes. Well differentiated tumours show pronounced keratinisation, pearl formation, and intercellular bridges in more than $50 \%$ of the tumour area. Moderately and poorly differentiated tumours show less evidence of keratinisation.

There is no squamous epithelium in the normal tracheobronchial tree. SCC of the lung is thought to arise from areas showing progressive mucosal changes, such as squamous metaplasia and dysplasia. It is widely believed that cigarette smoking and other environmental agents can cause such changes and the development of SCC of the lung..$^{7-11} 141$ Although we do not disagree with the proposed view of SCC tumorigenesis, our findings related to SCC of the lung in Okinawa suggest a close relation between SCC and HPV DNA, thus implicating the virus in tumorigenesis of at least this type of lung cancer. In this regard, HPV DNA has also been demonstrated in SCC components of a large number of adenosquamous carcinoma cases of the lung in Okinawa, ${ }^{25}$ and HPV was also considered to cause squamous metaplasia of adenocarcinoma. ${ }^{25}{ }^{29}$ As reported previously, ${ }^{5}$ there is no significant correlation between the degree of smoking and histological differentiation of these tumours, although Peter et al reported that smoking caused squamous metaplasia of the bronchial mucosa. ${ }^{32}$ Most patients with SCC in Okinawa as well as other regions were heavy smokers, and formerly many had well differentiated tumours. However, moderately or poorly differentiated tumours have become more prevalent in recent years, al- though most patients with these tumours are also heavy smokers. Thus, it seems that histopathological changes are not dependent on tobacco smoking. Furthermore, the prevalence of smoking in Okinawa in general has not been particularly high, and the average smoking habits of the patients has not changed. ${ }^{16}$

In Okinawa, most patients with SCC were men (379 of 421), and well differentiated cases with HPV infection were seen frequently. However, HPV positive well differentiated cases are decreasing. On the other hand, SCC in women was rare, and there were only eight well differentiated tumours. HPV was detected in only 12 female patients in 1993 and 1995-8, all of whom had well differentiated tumours. Lam et al have reported sex differences in bronchial epithelium, ${ }^{33}$ but further studies are needed.

HPV DNA was detected in $79 \%$ of SCCs of the lung surgically treated in Okinawa in 1993, and most tumours were well differentiated. This was particularly true for HPV types 6 and $16 .^{5}$ In a separate study, Papadopoulou et al also reported a correlation between well differentiated SCC of the lung and HPV types 16 and $18 .^{34}$ Since 1994 , the incidence of HPV in SCC of the lung has decreased in Okinawa. The number of tumours with double and triple types of HPV has also been decreasing steadily since 1995. In 1996, the number of SCC cases was higher than that of adenocarcinoma cases, but this was associated with a decrease in the number of well differentiated SCC cases. Thus, a low rate of HPV infection was coupled with a fall in the number of SCC cases, especially the well differentiated form. Tumour differentiation of SCC of the lung and frequency of HPV in Okinawa are currently similar to those of mainland Japan. In contrast, the age distribution, ratio of male to female patients, incidence of cigarette smoking, and the ratio of immunohistochemically p 53 protein positive cases $(32-44 \%$ of the cases were positively stained in each year) did not change significantly during the study period.

The Ile462Val polymorphism of cytochrome p450 IAl (CypIAl) is considered to be a high risk marker for lung cancer in Okinawan people, as reported recently by Sugimura et al. ${ }^{35}$ However, such polymorphism does not influence the histological differentiation of lung carcinoma. In addition, the incidence of SCC of the head and neck, oesophagus, and uterine cervix in Okinawa is 1.5-2.0 times higher than that of mainland Japan. ${ }^{1}$ Most of these tumours are positive for HPV. ${ }^{36}{ }^{37}$ Interestingly, the number of these tumours has also been falling in recent years. In this regard, the incidence of HPV in SCC varies significantly in different geographical regions. ${ }^{5171837-40}$ Taiwan, the nearest neighbour to Okinawa, and Fuzhou in China, which historically had close relations with Okinawa and was a source of immigration, have been reported as high HPV infection areas. ${ }^{41}{ }^{42}$ Okinawa was considered an HPV high prevalence region, but recent rapid improvements in hygiene (water supply, toilets, and sewage disposal) after Okinawa 
reverted to Japan ${ }^{4}$ have greatly reduced the incidence of HPV infection. This change is thought to have been followed by a decrease in the incidence of SCC, especially well differentiated cases.

In contrast to the above reports, Suzuk et al showed a lack of correlation between histological differentiation of oesophageal SCC and the presence of $\mathrm{HPV}{ }^{43}$ These discrepancies might result, in part, from the different detection systems and condition of the samples, ${ }^{5444}$ and geographical or environmental factors. ${ }^{42}{ }^{43} \mathrm{Re}$ cently, Gorgoulis et al reported that HPV was possibly involved in laryngeal but not in lung carcinogenesis. ${ }^{45}$ Our results, however, suggest that HPV might indeed be involved in the development of SCC of the lung. In 1995, the incidence of SCC in Okinawa fell below that of adenocarcinoma for the first time. Since then, the occurrence of SCC, particularly the well differentiated form has continued to decrease, and interestingly the decrease is closely related to the fall in HPV infection. However, in the case of low risk type HPVs, types 6 and 11, and HPV infection in a few SCC cases, viral infection might be secondary. Furthermore, in the well differentiated SCC cases, double or triple type HPV infection was considered to be a superimposed infection.

In conclusion, we demonstrated in this retrospective analysis of lung cancer cases a trend for increased incidence of adenocarcinomas and decreased incidence of SCC of the lung, especially the well differentiated form, in recent years in Okinawa. This fall in SCC coincided with a similar trend in the rate of HPV infection in SCC lesions, suggesting that at least in Okinawa island, HPV might be involved in the tumorigenesis and/or histological differentiation of SCC of the lung. Further laboratory studies are necessary to confirm our observations.

Most patients with SCC were men. No female patients had uterine cervical carcinoma. Cason et al have reported perinatal transmission of genital HPV, using a detection system sensitive to a broader range of HPV types. ${ }^{46}$ Further study is indicated into the correlation between female genital HPV types and HPV types in patients with lung cancer. ${ }^{47}$

1 Ministry of Health and Welfare of Japan. Statistics and information department. Malignant neoplasm of trachea, bronchus and lung. In: Age adjusted death rates from
malignant neoplasms by site. Each prefecture. Tokyo: Ministry of Health and Welfare, Japan, 1991:1-8.

2 Tominaga S, Mori T. Methods and results of lung cancer screening by municipalities in Japan [in Japanese]. Lung Cancer 1996;3:277-82.

3 Tominaga S. Epidemiology: increase of lung cancer patients [in Japanese]. Naika 1996;78:813-17.

4 Okinawa Prefectural Government. Annual statistical report of health and environment 1986-1995. Okinawa: Okinawa Prefectural Government, 1995.

5 Hirayasu T, Iwamasa T, Kamada Y, et al. Human papillomavirus DNA in squamous cell carcinoma of the lung. $\mathcal{F}$ Clin Pathol 1996;49:810-17.

6 Miyaji T. Histopathologic examination of 1152 cases of lung carcinoma [in Japanese]. Igaku no Ayumi 1961;36:256-62.

7 Carter D, Eggleston JC. Bronchogenic carcinoma. In: Hartmann WH, ed. Tumors of the lower respiratory tract. Atlas of
tumor pathology, Series 2, Fascicle 17. Washington DC: Armed Forces Institute of Pathology, 1980:59-69.

8 Colby TV, Koss MN, Travis WD. Carcinoma of the lung: overview, incidence, etiology, and screening. In: Rosai J, ed. Tumors of the lower respiratory tract. Atlas of tumor pathology,
Series 3, Fascicle 13. Washington DC: Armed Forces Institute of Pathology, 1995:91-106.
9 Gazdar AF, Linnoila RI. The pathology of lung cancer: changing concepts and newer diagnostic techniques. Semin Oncol 1988:15:214-25.

10 Mooi WJ, Addis BJ. Carcinoma of the lung. In: Corrin B, ed. Systemic pathology, 3rd ed, Vol. 5. The lung. Edinburgh: Churchill Livingstone, 1990:341-72.

11 Saldana MJ, Nones JM. Squamous cell carcinoma. In: Saldana MJ, ed. Pathology of pulmonary disease. Philadelphia: JB Lippincott, 1994:45-54.

12 Vincent RG, Pickren JW, Lane WW, et al. The changing histopathology of lung cancer. A review of 1682 cases. Cancer 1977;39:1647-55.

13 Travis WD, Lubin J, Ries L, et al. United States lung carcinoma incidence trends: declining for most histologic types among males, increasing among females. Cancer 1996;77: 2464-70.

14 Auerbach O, Garfinkel L, Parks VR. Histological type of lung cancer in relation to smoking habits, year of diagnosis lung cancer in relation to smoking habits, ye

15 Saldana MJ, Sridhar KS, Thurer RJ. Classification, and etiology of lung cancer. In: Saldana MJ, ed. Pathology of pulmonary disease. Philadelphia: JB Lippincott, 1994:52330

16 Oono Y, Kubo N, Hayashi Y. Clinicoepidemiological study on lung cancer and its relevant factors in Okinawa. In: Annual report of Kitsuen Kagaku Foundation. Tokyo: Japan Tobacco Co, 1988:5-17.

17 Kinoshita I, Dosaka-Akita H, Shindoh M, et al. Human papillomavirus type $18 \mathrm{DNA}$ and E6-E7 mRNA are detected in squamous cell carcinoma and adenocarcinoma of the lung. Br $\mathcal{F}$ Cancer 1995;71:344-9.

18 Osakabe Y, Wakasugi K, Shrestha B, et al. Detection of HPV with squamous cell carcinoma of the lung using in situ hybridization and catalyzed signal amplification system. Proceeding of the fapanese Society of Pathology 1997;86:233.

19 The Japan Lung Cancer Society. General rule for clinical and pathological record of lung cancer, 4th ed. Tokyo: Kanehara, 1995:90-104.

20 Fitzgibbons PL, Kern WH. Adenosquamous carcinoma of the lung. A clinical and pathologic study of seven cases. Hum Pathol 1985;16:463-6.

21 Cooper K, Herrington CS, Strickland JE, et al. Episomal and integrated human papillomavirus in cervical neoplasia shown by non-isotopic in situ hybridisation. 7 Clin Pathol 1991;44:990-6.

22 Impraim CC, Saiki RK, Erlich HA, et al. Analysis of DNA extracted from formalin-fixed, paraffin-embedded tissues
by enzymatic amplification and hybridization with sequence-specific oligonucleopeptides. Biochem Biophys Res Commun 1987;142:710-16.

23 Saiki RK, Scharf S, Faloona F, et al. Enzymatic amplification of $\beta$-globin genomic sequences and restriction site analysis for diagnosis of sickle cell anemia. Science 1985;230:1350-4

$24 \mathrm{McNicol}$ P, Paraskevas M, Guijon F. Variability of polymerase chain reaction-based detection of human papillomavirus DNA is associated with the composition of vaginal microbial flora. F Med Virol 1994;43:194-200.

25 Tsuhako K, Nakazato I, Hirayasu T, et al. Human papillomavirus DNA in adenosquamous carcinoma of the lung. F Clin Pathol 1998;51:741-9.

26 Shibata DK. The polymerase chain reaction and the molecular genetic analysis of tissue biopsies. In: Herrington CS, McGree JO'D, eds. Diagnostic molecular pathology. A practical approach, Vol. II. Oxford: Oxford University Press, 1992:85-111.

27 Walboomers JMM, Melkert PWJ, Van den Brule AJC, et al. The polymerase chain reaction for human papillomavirus screening in diagnostic cytopathology of the cervix. In: Herrington CS, McGree JO'D, eds. Diagnostic molecular pathology. A practical approach, Vol. II. Oxford: Oxford Unipathology. A practical approach,

28 Marchuk D, Drumm M, Saulino A, et al. Construction of T-vectors, a rapid and general system for direct cloning of unmodified PCR products. Nucleic Acids Res 1990;19: 1154

29 Nakazato I, Hirayasu T, Kamada Y, et al. Carcinoma of the lung in Okinawa, Japan: with special reference to squamous cell carcinoma and squamous metaplasia. Pathol Int 1997;47:659-72.

30 Fujimoto I, Nakamura M, Kitamura H, et al. A survey report on the size and nature of lung cancer problem in Japan, 1978 [in Japanese]. Lung Cancer 1985;3:291-6.

31 Wingo PA, Ries LAG, Giovino GA, et al. Annual report to the nation on status of cancer, 1973-1996, with a special section on lung cancer and Tobacco smoking. F Natl Cancer Inst 1999;91:675-90.

32 Peter EJ, Morice R, Benner SE, et al. Squamous metaplasia of the bronchial mucosa and its relationship to smoking. Chest 1993;103:1429-32.

33 Lam S, leRiche JC, Zheng Y, et al. Sex-related differences in bronchial epithelial changes associated with tobacco smoking. F Natl Cancer Inst 1999;91:691-6.

34 Papadopoulou K, Labropouloou V, Davaris $\mathrm{P}$, et al. Detection of human papilloma viruses in squamous cell carcinoma of the lung. Virchows Arch 1998;433:49-54.

35 Sugimura H, Wakai K, Genka K, et al. Association of Ile462Val (exon 7) polymorphism of cytochrome p450 IAl with lung cancer in the Asian population: further evidence with lung cancer in the Asian population: further evidence from a case-control study in Otir
Biomarkers Prev 1998;7:413-18.

36 Asato $\mathrm{T}$, Nakajima Y, Nagamine $M$, et al. Correlation between the progression of cervical dysplasia and prevalence of human papillomavirus. F Infect Dis 1994;169: 940-1. 
37 Tsuhako K, Hirayasu T, Iwamasa T. Human papillomavirus DNA in squamous cell carcinoma of the head and neck in Okinawa. Transactiones Societatis Pathologicae Japonicae 1996;85:268.

38 Bejui-Thivolet F, Liagre N, Chignol MC, et al. Detection of human papillomavirus DNA in squamous bronchial metaplasia and squamous cell carcinoma of the lung by in situ hybridization using biotinylated probes in paraffinembedded specimens. Hum Pathol 1990;21:111-16.

39 Syrjanen KJ, Syrjanen S, Kellokoski J, et al. Human papillomavirus DNA in bronchial squamous cell carcinomas. Lancet $1987 ; \mathbf{i}: 168-9$.

40 Yosen SA, Ohori NP, Sommez-Alpan E. Occurrence of human papillomavirus DNA in primary lung neoplasms. Cancer 1992;69:693-7.

41 Chang K-W, Chang C-S, Lai K-S, et al. High prevalence of human papillomavirus infection and possible association with betel quid chewing and smoking in oral epidermoid carcinomas in Taiwan. f Med Virol 1989;28:57-61.
42 Chen B, Yin H, Dhurandhar N. Detection of human papillomavirus DNA in esophageal squamous cell carcinomas by the polymerase chain reaction using general consensus primers. Hum Pathol 1994;25:920-3.

3 Suzuk L, Noffsinger AE, Hui ZY, et al. Detection of human papillomavirus in esophageal squamous cell carcinoma. Cancer 1996;78:704-10.

44 Wilczynski SP, Bergen S, Walker J, et al. Human papillomavirus and cervical cancer: analysis of histopathologic features associated with different viral types. Hum Pathol 1988;19:697-704.

45 Gorgoulis VG, Zacharatos P, Kotsinas A, et al. Human papillomavirus (HPV) is possibly involved in laryngeal but not in lung carcinogenesis. Hum Pathol 1999;30:274-83.

46 Cason J, Kaye JN, Jewers RJ, et al. Perinatal infection and persistence of human papillomavirus type 16 and 18 in persistence of human papillomavirus
infants. $\mathcal{F}$ Med Viol 1995;47:209-18.

47 Schneider A. Natural history of genital papillomavirus infections. Intervirology 1994;37:201-14. 